\title{
Effects of opioid and cholinergic receptors inhibition on the intestine hormones concentration and release in rats
}

\author{
K. Jaszcza', C.G. Scanes ${ }^{2}$, M. Capcarova ${ }^{3}$ and K. Pierzchała-Koziec ${ }^{1,4}$ \\ ${ }^{1}$ University of Agriculture in Krakow, Department of Animal Physiology and Endocrinology \\ Al. Adama Mickiewicza 24/28, 30-059 Kraków, Poland \\ 2 University of Arkansas, Centre of Excellence for Poultry Science Fayetteville, AR 72701, 479-575-2000, USA \\ ${ }^{3}$ Slovak University of Agriculture in Nitra, Department of Animal Physiology, Faculty of Biotechnology and Food Sciences \\ Tr. A. Hlinku 2, 94976 Nitra, Slovak Republic
}

KEY WORDS: ghrelin, mRNA, gastrin, somatostatin, enkephalin

Received: 1 July 2020

Revised: 24 July 2020

Accepted: 11 August 2020

${ }^{4}$ Corresponding author:

e-mail: rzkoziec@cyf-kr.edu.pl

\begin{abstract}
The aims of the study were: 1 . to evaluate the in vivo interaction of opioid and cholinergic receptors in the regulation of Met-enkephalins (native and total) and ghrelin concentrations in the rat intestine; 2 . to explore the association of opioids, muscarinic and nicotinic receptors in the regulation of in vitro secretion of peptidergic hormones such as Met-enkephalin, ghrelin, gastrin and somatostatin from rat intestine. Two experiments were performed on adult, male Wistar rats: 1. in in vivo experiment animals received a single intraperitoneal injection of $\mathrm{NaCl}$ (control), naltrexone (opioid receptor antagonist), atropine (muscarinic receptor antagonist) or hexamethonium (nicotinic receptor antagonist), and Metenkephalins concentration and expression of mRNA for proenkephalin, and ghrelin concentration were measured in the intestine; 2 . in in vitro experiments above receptors antagonists were added to tissue culture alone or in combination; native Met-enkephalin, ghrelin, gastrin and somatostatin concentrations were measured in the medium. In vivo inhibition of receptors increased the concentration of total Met-enkephalin and potentiated the expression of mRNA for proenkephalin. Ghrelin concentration was increased by naltrexone and decreased by atropine. In vitro secretion of Met-enkephalin was decreased by both cholinergic receptor antagonists but this effect was fully reversed by naltrexone. Ghrelin and gastrin release from the intestine was increased by all three antagonists given alone; in vitro somatostatin release from the intestine was attenuated by receptor antagonists given alone or in combination. The obtained results clearly showed the interaction of opioids and acetylcholine in the regulation of synthesis, concentration and release of peptidergic hormones from the rat intestine.
\end{abstract}

\section{Introduction}

The nervous system and the gastrointestinal (GI) tract share several common features including reciprocal interconnections and several neurotransmitters and peptides known as gut peptides, neuropeptides or hormones. The processes of digestion, secretion of digestive enzymes and then absorption are regulated by the neuroendocrine system (Goldspink et al., 2018). It was found that enteric nervous system (ENS) is a component of the neural control systems and affects the intestinal motility, fluid transport, blood flow and nutrient ingestion (Gribble and Reimann, 2019). 
In the ENS, acetylcholine is the most common neurotransmitter to induce gastrointestinal smooth muscle contractions (Skulsky et al., 2007). Acetylcholine receptors (AChRs) in the gastrointestinal tract are represented by the metabotropic muscarinic receptors (Abrams et al., 2006) and the ionotropic nicotinic receptors (Albuquerque et al., 2009). Both share the property of being activated by the endogenous neurotransmitter acetylcholine (ACh), and they are expressed by neuronal and nonneuronal cells throughout the body (Foong et al., 2015).

Enteric neurons synthesize and release not only acetylcholine, substance $\mathrm{P}$ but also opioid peptides serving as their transmitters (Holzer, 2009). Opioids affect primarily neuronal excitability in the enteric circuitry by the interaction with the ENS neurotransmitters. The major effects of opioid receptor agonists in the GI tract are reduction of contractions and impairment of peristalsis by inhibition of the release of acetylcholine and substance $\mathrm{P}$, as well as decrease of GI peptides secretion by lowering the activity of ACh-containing neurons.

In the GI tract, opioid receptors: mi for endorphins (MOR), delta for enkephalins (DOR) and kappa for dynorphins (KOR) are localized on enteric neurons, interstitial cells of Cajal and immune cells. In humans, opioid receptors link to inhibition of $\mathrm{ACh}$ release from enteric interneurons and motorneurons. Enkephalins are short opioid peptides, which are produced mainly by the pituitary, adrenal glands and the GI tract where they are formed in gastric and intestinal endocrine cells (Sobczak et al., 2014). There are two enkephalins, Leu- and Met-enkephalin existing in the native, short form and total, extended proenkephalin form. Both peptides are potent DOR agonists, and additionally possess some affinity to MOR. The major physiological effect of enkephalins is antinociception and inhibition of pain signaling in the central nervous system (CNS) and the periphery, including the GI tract (Galligan and Sternini, 2017).

Met-enkephalin, can regulate intestinal secretion by acting directly on enterocytes. In previous experiments it was suggested that enterocytes isolated from the crypt epithelium of guinea pigs have both mi- and delta-types of opioid receptors (Lang et al., 1996). It is possible that these cells participate in opioid-mediated regulation of intestinal secretion. Opioids reduce epithelial secretion and promote water and electrolyte absorption mainly by the activation of DOR and MOR (Galligan and Sternini, 2017).

Enterocytes and ENS cells express muscarinic and cholinergic receptors as well as opioids recep- tors (Galligan and Sternini, 2017), which may suggest that their interaction affects synthesis and release of many peptidergic hormones existing in GI tract such as ghrelin, gastrin and somatostatin.

Ghrelin, called a stimulator of appetite, was found in the GI system and in many other tissues as liver, pancreas, heart, adrenal and nervous system. Previously, it was also found that Met-enkephalin interacts with the ghrelin activity at the GI and CNS levels under stressful situations (Dyaczyński et al., 2018).

Gastrin is a family of several peptides of varying length with different degrees of biological activity. It is released from gastric antrum and duodenum ( $G$ cells) in response to direct contact with meal and stomach distension. Physiologically, gastrin is responsible for increasing the secretion of hydrochloric acid, stomach and pancreatic enzymes and inhibiting/reducing the appetite. The gastrin gene is expressed and gastrin is secreted in a variety of cells: of small and large intestine (duodenal, jejunal, ileal and colonic mucosas), pancreas and neuroendocrine tissue (Copps et al., 2009).

Since its isolation from the hypothalamus in 1973 by Guillemin's group somatostatin has been found in almost all peripheral tissues. In the GI tract somatostatin was found in extrinsic and intrinsic neurons of ENS and in endocrine D cells of gastric and duodenal epithelia (Lewin, 1992). In the GI tract, somatostatin acts as a local tissue hormone, which influences endocrine and other cells in the mucosa in autocrine or paracrine manner. Somatostatin lowers gastrin secretion and hydrochloric acid production, and in the small intestine it lowers the secretion of a number of other GI hormones (Makowska, 2019).

Disorders of GI system are common in animals and humans and caused a lot of problems such as pain, inflammation, constipation, diarrhoea, irritable bowel syndrome, infections, colitis, colon polyps and cancer. Many of these illness are functional or motility disorders, influencing stability of endocrine, nervous and immune systems (Montgomery et al., 2016).

Unfortunately, an excessive action of opioids/ opiates released as a native peptides or given pharmacologically as the analgesics, inhibits the processes of GI system and might cause significant health problems for humans and animals.

Many anatomical and biochemical evidences indicate that opioidergic and cholinergic systems are co-localized and also act on the same neurons (Sobczak et al., 2014). However, in spite of extended research, the regulatory mechanisms 
between cholinergic and opioidergic systems during activation/inhibition of synthesis and releasing of GI peptides have not been well characterized, yet.

Thus, the aims of the study were: 1 . to evaluate the in vivo interaction of opioid and cholinergic receptors in the regulation of Met-enkephalin and ghrelin concentrations in the rat intestine; 2 . to explore the association of opioids and muscarinic and nicotinic receptors in the regulation of in vitro secretion of peptidergic hormones such as Metenkephalin, ghrelin, gastrin and somatostatin from the rat intestine.

\section{Material and methods}

The protocol was approved by the First Local Ethical Committee on Animal Testing in Krakow (131/2013/I LKE).

\section{Experiment 1. The effects of opioid, nicotinic and muscarinic receptors antagonists on the ghrelin and Met-enkephalin synthesis and concentration in the rat intestine}

The experiment was carried out on male Wistar rats (body weight (BW) 220 g, n = 24) kept in standard conditions (individual cages) with ad libitum access to commercial feed and water. After adaptation to laboratory conditions, rats were divided into 4 groups (control and 3 experimental); animals received a single intraperitoneal (i.p.) injection of physiological solution (control group); $3 \mathrm{mg} / \mathrm{kg} \mathrm{BW}$ of naltrexone ( $\mathrm{N}$ group); $5 \mathrm{mg} / \mathrm{kg} \mathrm{BW}$ of atropine (A group); and $5 \mathrm{mg} / \mathrm{kg} \mathrm{BW}$ of hexamethonium (H group). Thirty minutes after injection animals were euthanized by injection of $26 \mathrm{mg} / \mathrm{kg} \mathrm{BW}$ of pentobarbital according to AVMA Guidelines for the Euthanasia of Animals (AVMA, 2020). Fragments of intestine (duodenum) were immediately dissected and divided into two parts (around $100 \mathrm{mg}$ ) for estimation of hormones concentration (frozen at $-80^{\circ} \mathrm{C}$ ) and for mRNA expression of proenkephalin (PENK) (frozen at $-80^{\circ} \mathrm{C}$ ).

\section{Experiment 2. The effects of opioid, nicotinic and muscarinic receptors antagonists on the in vitro release of hormones from the rat intestine}

The tissues for the experiment 2 were collected from the intact male Wistar rats (BW $220 \mathrm{~g}, \mathrm{n}=6$ ) kept in the standard conditions identical to those in the Experiment 1 . After rat euthanasia fragments of intes- tine (duodenum) were immediately dissected, divided into six parts (around $50 \mathrm{mg}$ each) for the in vitro hormones release analysis and kept in the cold Krebs buffer.

\section{Methods}

Estimation of hormones concentration in the tissue and in the culture medium. Ghrelin and Metenkephalins levels in the tissues were estimated by radioimmunoassay method (ghrelin-commercial kit from Phoenix Pharmaceuticals, Belmont, CA, USA) and method evolved by Pierzchala and Van Loon for enkephalins (Pierzchala and Van Loon, 1990).

Gastrin and somatostatin concentrations in the culture medium were estimated by the radioimmunoassay using commercial kits from DRG-MedTek (DRG Instruments $\mathrm{GmbH}, \mathrm{R} \& \mathrm{D}$ and Production, Marburg, Germany).

PENK mRNA gene expression. PENK mRNA gene expression was estimated by modified method described by Lightman and Young (1987). Briefly, the frozen fragments of intestine were sliced (14 $\mu \mathrm{m}$ sections) using a Leica cryostat microtome $\left(-22{ }^{\circ} \mathrm{C}\right)$. The sections were thawmounted on gelatin-covered microscopic slides, and stored for 3 days at $-20{ }^{\circ} \mathrm{C}$ before the assay. Then, tissue sections were thawed and fixed in $4 \%$ formaldehyde in phosphate buffered saline (PBS; pH 7.4) for $10 \mathrm{~min}$. Next, sections were acylated for $10 \mathrm{~min}$ in triethanolamine/acetic anhydride $(0.25 \%)$. Sections were dehydrated by immersion through graded ethanol (70\%, 80\%, $95 \%, 100 \%$ ) and air-dried. After pre-hybridization, a synthetic deoxyoligonucleotide, complementary to the fragment of rat PENK, was labelled using ${ }^{35} \mathrm{~S}-\mathrm{dATP}(1200 \mathrm{Ci} / \mathrm{nmol})$ to obtain a specific activity about $4 \times 106 \mathrm{cpm} / \mu \mathrm{l}$. The probes were diluted in a hybridization buffer (formamide, dextran sulphate, saline-sodium citrate buffer (SSC), Denhardt's solution, yeast tRNA, herring sperm DNA). Hybridization occurred after $20 \mathrm{~h}$ in humidified chamber at $37^{\circ} \mathrm{C}$. Then, the sections were washed once in SSC for $10 \mathrm{~min}$, then four times for $15 \mathrm{~min}$, each in $\mathrm{SSC} / 50 \%$ formamide at $40{ }^{\circ} \mathrm{C}$, rinsed in $\mathrm{SSC}$ and distilled water at room temperature and air-dried. The sections were exposed to Kodak film for 4 weeks $\left(-80{ }^{\circ} \mathrm{C}\right)$. The photo-stimulated luminescence (PSL) density of the irradiated plates was measured with BAS-1000 readout system. The PSL $/ \mathrm{mm}^{2}$ at the resultant film images was determined using computer image analysis system. 
In vitro Met-enkephalin, ghrelin, gastrin and somatostatin secretions. Met-enkephalin as well as other hormones secretions from fragments of tissues were estimated according to the method of Kowalski and Giraud (1993) with some modifications. Briefly, 6 fragments of tissues (50-60 mg) sliced by microtome were placed into 24-well plates with $2 \mathrm{ml}$ of Krebs-Ringer bicarbonate buffer (medium). Groups of intestine were treated with antagonists: $100 \mu \mathrm{l}$ of $\mathrm{NaCl}$ (control), $100 \mathrm{nM}$ of atropine $(\mathrm{A})$, hexamethonium $(\mathrm{H})$, naltrexone $(\mathrm{N})$, atropine plus hexamethonium $(\mathrm{A}+\mathrm{H})$ and atropine plus hexamethonium plus naltrexone $(\mathrm{N}+\mathrm{A}+\mathrm{H})$.

\section{Results}

\section{Hormones concentration in the tissue (Experiment 1, Table 1)}

Met-enkephalin concentration. Injection of naltrexone significantly decreased the concentration of native Met-enkephalin in the intestine from $39.5 \pm 2.5$ in control rats to $22.5 \pm 1.9 \mathrm{fmol} / \mathrm{mg}$ protein $(P<0.05)$. In contrast, concentration of total Met-enkephalin and expression of mRNA for PENK were increased after inhibition of the opioid receptors $(P<0.05)$, by 53.4 and $90.9 \%$, respectively.

Table 1. The effects of opioid and cholinergic receptors antagonists on concentrations of native and total Met-enkephalin, mRNA of proenkephalin and ghrelin in the rat intestine $(x \pm S E M)$

\begin{tabular}{lllll}
\hline \multirow{2}{*}{ Indices } & Groups & & & \\
\cline { 2 - 4 } & control & $\mathrm{N}$ & $\mathrm{A}$ & $\mathrm{H}$ \\
\hline Native Met-enkephalin, fmol/mg protein & $39.5 \pm 2.5^{\mathrm{a}}$ & $22.5 \pm 1.9^{\mathrm{b}}$ & $43.5 \pm 3.7^{\mathrm{a}}$ & $33.5 \pm 2.9^{\mathrm{ac}}$ \\
Total Met-enkephalin, fmol/mg protein & $486 \pm 33^{\mathrm{a}}$ & $746 \pm 65^{\mathrm{b}}$ & $840 \pm 66^{\mathrm{c}}$ & $705 \pm 55^{\mathrm{bd}}$ \\
mRNA proenkephalin, PSL/mm² & $303 \pm 20.3^{\mathrm{a}}$ & $630 \pm 12.6^{\mathrm{b}}$ & $770 \pm 22.5^{\mathrm{b}}$ & $586 \pm 41.8^{\mathrm{bc}}$ \\
Ghrelin, fmol/mg protein & $356 \pm 33^{\mathrm{a}}$ & $573 \pm 43^{\mathrm{b}}$ & $266 \pm 21^{\mathrm{c}}$ & $291 \pm 23^{\mathrm{ac}}$ \\
\hline
\end{tabular}

1 - animals received: a single intraperitoneal injection of physiological solution (control group); $3 \mathrm{mg} / \mathrm{kg}$ body weight (BW) of naltrexone ( $\mathrm{N}$ group); $5 \mathrm{mg} / \mathrm{kg} \mathrm{BW}$ of atropine (A group) and $5 \mathrm{mg} / \mathrm{kg} \mathrm{BW}$ of hexamethonium (H group); PSL - photo-stimulated luminescence; ${ }^{\mathrm{a}-\mathrm{d}}-\mathrm{values}$ with different superscripts are significantly different at $P<0.05$

After a 30 -min preincubation period, tissues were incubated at $37^{\circ} \mathrm{C}$ for five successive 30 -min periods in $2 \mathrm{ml}$ of medium according to the sequence: 1 . basal medium; 2. stimulating medium with $100 \mathrm{nM}$ of opioids or cholinergic receptors antagonists; 3. basal medium; 4. basal medium; 5 . stimulating medium with $56 \mathrm{mM} \mathrm{KCl}$. Stimulation with $\mathrm{KCl}$ served to validate survival of the tissue through the experiment. The concentration of Met-enkephalin, ghrelin, gastrin and somatostatin in the basal media were not significantly different, so the results were pooled and presented as hormones release under basal conditions.

Protein estimation. Concentrations of all hormones in the tissues or incubation media were calculated per mg of total protein. Proteins were estimated by Folin-Ciocalteu reagent (FCR) according to Lowry et al. (1951).

\section{Statistical analysis}

The obtained results were tested for the homogeneity of variances (Hartley-Cochran-Bartlett test) and the normality of distribution (Shapiro-Wilk test). The data were analysed statistically by one-way analysis of variance (ANOVA) followed by the Fisher LSD post-hoc test. All results were expressed as mean value and standard error of means $(\mathrm{X} \pm \mathrm{SEM})$. A value of $P<0.05$ was considered statistically significant.
Inhibition of muscarinic receptors by atropine caused increase of total Met-enkephalin concentration by $72.7 \%$ (to $840 \pm 66 \mathrm{fmol} / \mathrm{mg}$ protein, $P<0.05)$ as well as the expression of mRNA for PENK (increase to $770 \pm 22.5 \mathrm{PSL} / \mathrm{mm}^{2}, 133.3 \%$, $P<0.05)$. Similarly to atropine, hexamethonium did not changed the native Met-enkephalin concentration, but significantly $(P<0.05)$ increased the total Met-enkephalin concentration (by $44.9 \%$ ) and expression of mRNA PENK (by 75.8\%).

Ghrelin concentration. Injection of naltrexone increased the tissue concentration of ghrelin from $356 \pm 33$ to $573 \pm 43 \mathrm{fmol} / \mathrm{mg}$ protein $(P<0.05$, $60.9 \%)$. Unexpectedly, nicotinic cholinergic receptors inhibition did not change the peptide concentration in the rat intestine. In contrast, atropine decreased the concentration of ghrelin from $356 \pm 33$ to $266 \pm 21 \mathrm{fmol} / \mathrm{mg}$ protein $(P<0.05)$.

\section{Peptidergic hormones in vitro release from intestine (Experiment 2)}

Met-enkephalin (Figure 1). Native Metenkephalin release from intestine was decreased by both cholinergic receptors antagonists (atropine and hexamethonium $)(P<0.05)$ by 90.9 and $28.6 \%$, respectively. In contrast, naltrexone alone potentiated the in vitro release of Met-enkephalin (by $66.7 \%, P<0.05$ ). Naltrexone added together with 


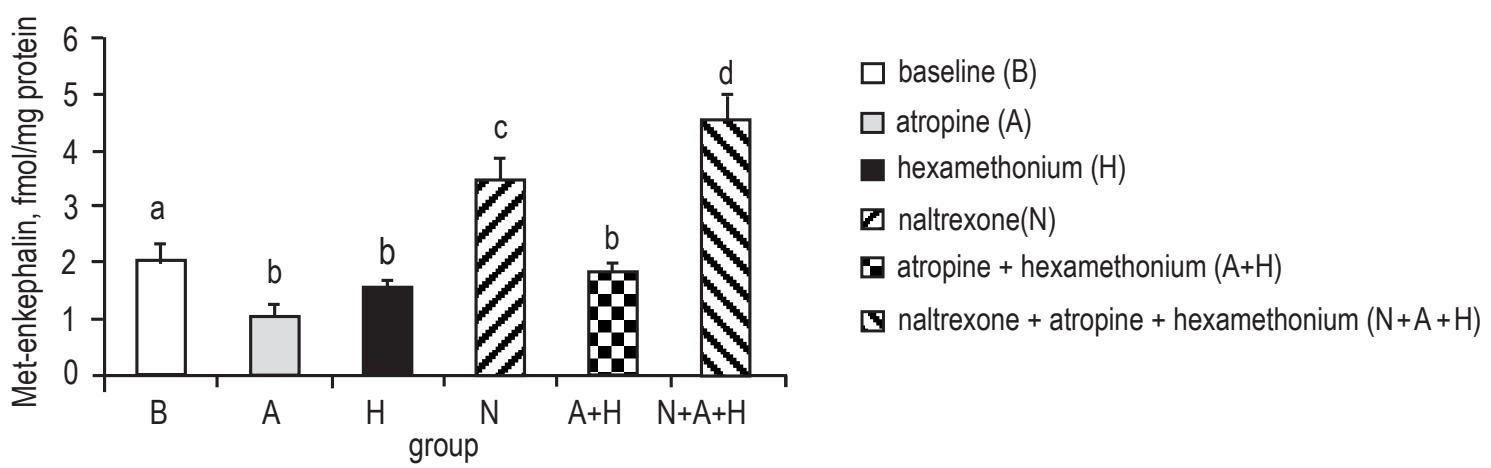

Figure 1. Effects of opioid and cholinergic receptors antagonists on the in vitro secretion of native Met-enkephalin from the rat intestine (fmol/mg protein, $\mathrm{x} \pm \mathrm{SEM}$ ). $\mathrm{a}-\mathrm{d}$ - bars with different superscripts are significantly different at $P<0.05$.

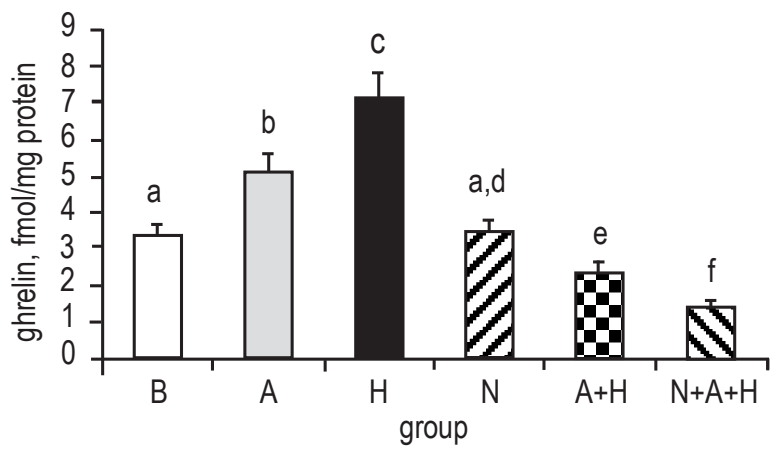

\author{
$\square$ baseline (B) \\ $\square$ atropine $(\mathrm{A})$ \\ hexamethonium $(\mathrm{H})$ \\ $\square$ naltrexone(N) \\ atropine + hexamethonium $(\mathrm{A}+\mathrm{H})$ \\ naltrexone + atropine + hexamethonium $(\mathrm{N}+\mathrm{A}+\mathrm{H})$
}

Figure 2. Effects of opioid and cholinergic receptors antagonists on the in vitro secretion of ghrelin from rat the intestine (fmol/mg protein, $\mathrm{X} \pm \mathrm{SEM}$ ). a $-\mathrm{f}-$ bars with different superscripts are significantly different at $P<0.05$.

both cholinergic receptors antagonists stimulated Met-enkephalin in vitro release from intestine by $114.5 \%(P<0.05)$.

Ghrelin (Figure 2). Atropine increased ghrelin release from the basal level of $3.2 \pm 0.15$ to $5.1 \pm 0.3 \mathrm{fmol} / \mathrm{mg}$ protein $(P<0.5)$; hexamethonium potentiated the hormone release by $121.9 \%$ to $7.1 \pm 0.7 \mathrm{fmol} / \mathrm{mg}$ protein $(P<0.05)$. Unexpectedly, combination of atropine and hexamethonium decreased the ghrelin release by $28 \%(P<0.05)$.

Blockade of opioid receptors by naltrexone alone did not change the level of ghrelin secretion but in combination with both cholinergic receptors antagonists significantly decreased the ghrelin release to the level of $1.4 \pm 0.11 \mathrm{fmol} / \mathrm{mg}$ protein (fall by $56 \%, P<0.05$ ).

Gastrin (Figure 3). Both cholinergic receptors antagonists added separately to the medium increased the gastrin release from the intestine by $201.5 \%$ after atropine from the basal level of $1.33 \pm 0.11$ to $4.01 \pm 0.33 \mathrm{fmol} / \mathrm{mg}$ protein $(P<0.05)$, and more than 11 times by hexamethonium to the level of $17.12 \pm 1.35 \mathrm{fmol} / \mathrm{mg}$ protein $(P<0.05)$. Similarly to ghrelin, combined addition of atropine and hexamethonium caused inhibition of gastrin secretion $(P<0.05)$.

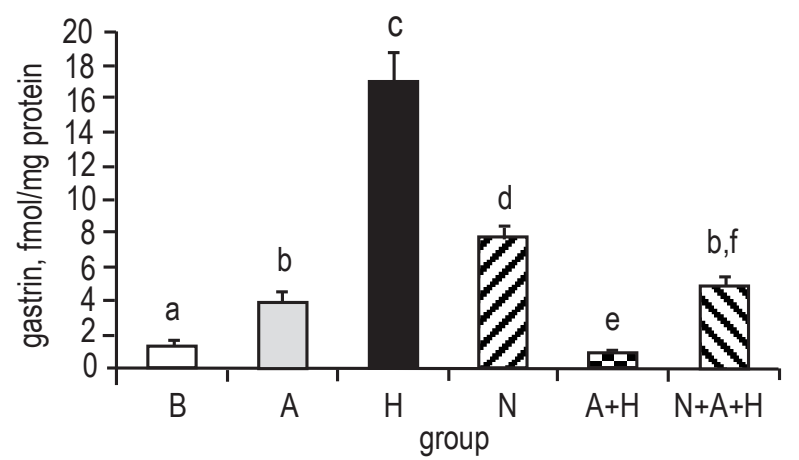

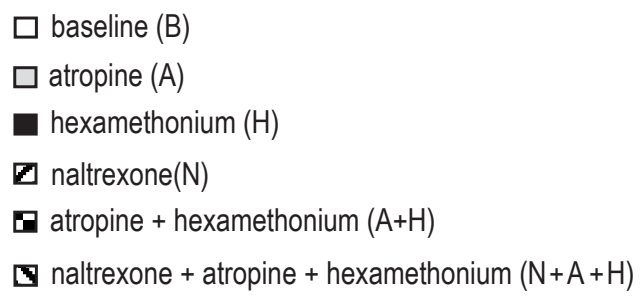

Figure 3. Effects of opioid and cholinergic receptors antagonists on the in vitro secretion of gastrin from rat the intestine (fmol/mg protein, $\mathrm{x} \pm$ SEM). $a-f-$ bars with different superscripts are significantly different at $P<0.05$. 
Naltrexone alone caused increase of gastrin secretion up to $7.63 \pm 0.55 \mathrm{fmol} / \mathrm{mg}$ protein $(P<0.05)$, however added together with muscarinic and nicotinic receptors antagonists increased the hormone release only to $4.77 \pm 0.35 \mathrm{fmol} / \mathrm{mg}$ protein $(P<0.05)$.

Somatostatin (Figure 4). Opioid receptor antagonist and cholinergic receptors antagonists significantly attenuated somatostatin release from the rat intestine in in vitro conditions, however their effect was different - the lowest change was observed after hexamethonium (decrease by $39.3 \%, P<0.05$ ), the highest - after atropine + hexamethonium addition (decrease by $73.5 \%, P<0.05$ ).

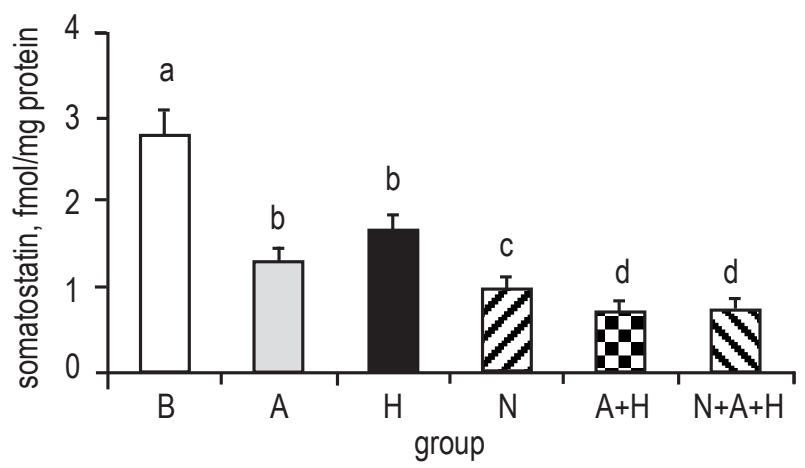

The opioid peptides of the gut, mainly $\beta$-endorphin and Met-enkephalin are present in the neurones of the myenteric plexus. Axonal projections from these neurones innervate the circular muscle layer and reach the myenteric Auerbach plexus. Neural receptors for the opioid peptides have been identified in the myenteric plexus causing hyperpolarization of neurones, inhibition of ACh release and blockade of muscle contraction. Recently, it was found that opioid receptors are co-expressed in cholinergic neurons of mouse ileum myenteric plexus (Altarifi et al., 2017).

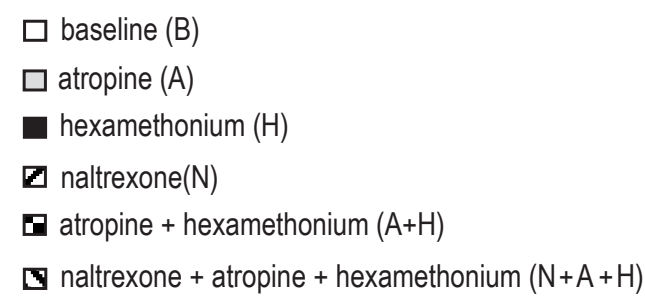

Figure 4. Effects of opioid and cholinergic receptors antagonists on the in vitro secretion of somatostatin from the rat intestine (fmol/mg protein, $\mathrm{x} \pm \mathrm{SEM}$ ). $\mathrm{a}-\mathrm{d}$ - bars with different superscripts are significantly different at $P<0.05$.

\section{Discussion}

Enteroendocrine cells, the largest and most diverse population of mammalian endocrine cells, comprise a number of different cell types in the gut mucosa that synthesize store and secrete peptides and larger proteins that are involved into regulation of many aspects of gut physiology. Most enteroendocrine cells release their hormones or regulatory peptides into the local environment from which they act in paracrine manner, reach nerve endings or enter the blood. Although the endocrine cells are present in all parts of the intestine, in the present experiments we have focused on the duodenum, where sensory cells are predominant and determine contents entering from the stomach and send signals to other organ systems. These signals are necessary to effectively process and utilize the food or defend the organism against possible harmful chemicals or toxins. The endogenous opioids and opioid receptors that participate in these physiologic processes are expressed by neurons in the gut where they mediate functions such as gastric emptying, gut motility and intestinal secretion (Holzer, 2009; Galligan and Sternini, 2017).
Expression of proopiomelanocortin and PENK was found in several parts of intestine and proved that their native forms $-\beta$-endorphin and Met-enkephalin were secreted in the gastric, duodenal and jejunal lumena. However, little is known about the types of cells that are the source of endogenous opioid peptides delivered to the gut lumen (Altarifi et al., 2017).

In the first experiment (in vivo) inhibition of opioid receptors by injection of naltrexone decreased the native, five amino acids Met-enkephalin concentration in the intestine along with the significant increase of total form (PENK) of the opioid. It seems probable that antagonist blocking the opioid receptors in the duodenum caused immediate release of the native form of Met-enkephalin from the nerves to the intestine lumen. Previously, it was found that naltrexone decreased the level of native Met-enkephalin in various tissues throughout the body. Interestingly, the concentration of total Met-enkephalin which contains mainly PENK was increased by $54 \%$ in the tested duodenum fragments. Probably, PENK was not processed by hydrolytic enzymes to the native, biologically active peptide. Moreover, the mRNA expression of PENK was increased by more than $90 \%$ after naltrexone injection, which may suggest the 
stimulation of the synthesis by negative feedback, $\mathrm{ACh}$, gastrointestinal hormones or by unidentified factors.

Interestingly, naltrexone affected also ghrelin secretion or/and synthesis in the duodenum increasing its concentration almost by $61 \%$. Interaction of opioids and ghrelin was found in lamb, piglet (Pierzchała-Koziec, 2012) and human (Dyaczyński et al., 2020). It can be speculated that endogenous opioids in the gut may have a local modulating effect on the ghrelin secretion. In this case, low level of the native, physiologically active enkephalin along with the blocked opioid receptors caused inhibition of ghrelin secretion which resulted in higher concentrations of both - total Met-enkephalin and ghrelin in the duodenum tissue.

In contrast to naltrexone, injections of cholinergic antagonists atropine (muscarinic receptor) and hexamethonium (nicotinic receptors) did not affect the concentration of native Met-enkephalin, but again increased the concentration of total form of enkephalin as well as mRNA PENK expression. It is worth to emphasize that the stimulating effect of muscarinic receptors inhibition was much stronger than that caused by hexamethonium. Similarly to this, only atropine significantly decreased ghrelin concentration in the duodenum, the diminishing effect of hexamethonium on the ghrelin was weak and caused only tendency to lower the peptide level. Probably, the muscarinic and nicotinic receptors distribution in the duodenum is variable and their activation by agonists and inhibition by antagonists lasted for different period of time.

These suggestions are in agreement with the fact that activation of muscarinic receptors causes excitatory input for GI motility (Sobczak et al., 2014). From the five muscarinic receptors subtypes (M1-M5) only M2 and M3 are present on the smooth muscle cells of GI tract and expressed at ratio 3:1, respectively. The muscarinic metabotropic receptors are second messenger, $\mathrm{G}$ protein-coupled seven-transmembrane proteins. Activation of muscarinic acetylcholine receptors (mAChRs) is relatively slow (milliseconds to seconds) and, depending on the subtypes present (M2-M3), they directly alter cellular homeostasis of phospholipase $\mathrm{C}$, inositol trisphosphate, cAMP and free calcium (Takeuchi et al., 2006).

On the other hand, the fast ionotropic cationic nicotinic receptor channel (nAChR) activity is induced in the micro- to submicrosecond range and the effect on the release and/or synthesis of hormones lasted for very short time making impossible to notice the changes (Takeuchi et al., 2006).
These results revealed the presence of opioid receptors delta and proved the synthesis of enkephalin and ghrelin in the duodenum cells and showed the interaction with cholinergic receptors.

However, the question is arising - how the inhibition of cholinergic and opioid receptors affect (directly or indirectly) the secretion of Met-enkephalin, ghrelin, gastrin and somatostatin from duodenum. In order to find the answer, we created the model for in vitro peptides secretion based on the short cell culture method enabling to estimate immediate stimulation/ inhibition of hormones release into the medium (in vitro experiment).

Basal in vitro release of native Met-enkephalin from the intestine fragments was only $5 \%$ of that level measured in the intestine in in vivo condition $(2.1 \pm 0.1 \mathrm{vs} 39.5 \pm 2.5 \mathrm{fmol} / \mathrm{mg}$ protein, respective1y). Increased opioid secretion by naltrexone was in the agreement with the result observed in the in vivo experiment in which the native Met-enkephalin level was decreased. It can be speculated that low-dose naltrexone (LDN) used in our in vivo and in vitro experiments acted as a partial agonist and stimulated the release of native Met-enkephalin which has potential as an anti-inflammatory agent. In the review of Parker et al. (2018) it was shown that LDN has positive anti-inflammatory effect in patients with Crohn's disease and taking into account that Met-enkephalin decreases inflammation, higher degree of this peptide secretion may help in modulating this pathology. Owczarek et al. (2011) demonstrated that serum free (native) Met-enkephalin levels were depressed in patients with inflammatory bowel disease (IBD). Conversely, Met-enkephalin levels in colonic biopsies collected from inflammatory lesions of IBD patients were significantly higher as compared to sections without inflammatory lesions and their level correlated with disease activity. Altogether, the changes of synthesis, secretion of Met-enkephalin indicate that endogenous opioid plays also a role in the antiinflammatory process in the GI tract.

Interestingly, atropine and hexamethonium added separately or gradually to the cell culture decreased the in vitro Met-enkephalin secretion. It seems that the cholinergic nerves activity is necessary to control the opioids release via ACh. Unexpectedly, naltrexone reversed this diminishing effect of both cholinergic receptor antagonists on the opioid secretion and significantly increased the Met-enkephalin secretion. Possibly, in in vitro conditions the lack of acetylcholine and additional unspecified factors (enzymes/hormones) let naltrexone fully stimulate the release of opioid peptide from the intestine (Kokrashvili et al., 2009). 
Quite opposite results were obtained for ghrelin secretion from the intestine - naltrexone itself did not affect the release of this hormone, but both cholinergic receptors antagonists added separately increased in vitro ghrelin secretion. Intriguing result was observed after treating the tissue consecutively with both - atropine and hexamethonium, because the ghrelin secretion was lowered below the basal level. It seems probable that inhibition of muscarinic and nicotinic receptors and lack of ACh activity prevents the ghrelin stimulation in the intestine. Similar results were obtained in rats after vagotomy, which inhibited the release of ghrelin from the stomach and duodenum fragments (Dyaczyński et al., 2018). Vagotomy also changed the concentration of ghrelin and Met-enkephalin in the GI tract indicating the interaction of ghrelin, opioids and vagus nerve (Wieczorek and PierzchalaKoziec, unpublished results). These findings are in contrast to results obtained in experiments on sheep, in which ACh decreased the secretion of ghrelin (Scerif et al., 2011), therefore extrapolating results from rodents to another species should be very cautious.

In vitro gastrin secretion from the intestine was increased by atropine and hexamethonium, however in different degree. Since gastrin release is directly stimulated by $\mathrm{ACh}$ released from vagal fibres predominantly via muscarinic receptors (Copps et al., 2009), it may be speculated that inhibition of these receptors by atropine reciprocally stimulated the activity of nicotinic receptors, which are less involved in this process. In turn, blockade of nicotinic receptors by hexamethonium, potentiated the activity of muscarinic receptors and the level of secreted gastrin to the culture media was significantly higher in comparison to the amount of hormone released after atropine treatment.

Interesting results were obtained after treatment with opioid receptors antagonist - naltrexone, which potentiated the in vitro gastrin release when added separately. However, naltrexone partially reversed the diminishing effect of both cholinergic receptors antagonists and significantly increased the gastrin release. It may be suggested that increased secretion of Met-enkephalin after naltrexone supplementation partially lowered the level of $\mathrm{ACh}$ and the secretion of gastrin was modulated according to various cholinergic receptors activity. The very first results obtained by Impicciatore et al. (1977) showed that in human a small dose of atropine increases the gastrin release to feeding, however the mechanism was unclear.
This suggests that opioids are the link between $\mathrm{ACh}$ and gastrin in mediation of nervous and endocrine activity in the GI system.

Supplementation of opioid and cholinergic receptors antagonists significantly decreased the somatostatin release from the intestine cells, however the diminishing effect of naltrexone given alone or in combination with atropine and hexamethonium was stronger than cholinergic antagonists. Somatostatin is the main hormone controlling the activity of all other GI hormones directly via specific receptors or indirectly by inhibiting synthesis, secretion and function of hormones. Somatostatin causes relaxation of the intestinal smooth muscles, reduces the secretion of digestive enzymes and gut hormones (Thompson et al., 2014).

Unexpectedly, in the present in vitro experiment was clearly shown that inhibited activity of cholinergic and opioid receptors, and in turn lack of $\mathrm{ACh}$, had enormous attenuated effect on the somatostatin release from the intestine.

It may be speculated that in the GI tract there is extended bilateral relationship between the peptidergic hormones, their receptors and vagus nerve.

\section{Contribution to the field}

We have evaluated in vivo interaction of opioid and cholinergic receptors in the regulation of Met-enkephalin and ghrelin concentrations in the rat intestine. Additionally, we have provided evidence for functional selectivity of opioid and cholinergic receptors and discussed potential issues related to translation of organ-derived data to the whole animal levels. Selective stimulation of hormones release may be possible when agonists are expressed by distinct cells or neuronal subtypes. Peptides differ with their susceptibility to degradation, complicating the interpretation of studies of duration or magnitude of effects. Furthermore, these peptides vary in their relative affinities to specific receptors. The endpoints that we measured may be indirect and result from activation of complex pathways involving a number of other, unspecified transmitters. However, understanding the fundamental basis for agonists/antagonists bias and determining whether differences in the expression and release of intestine hormones underlie the development and maintenance of disease may be more promising way to provide future insight for the development of safer therapies. 
In the present studies it was shown strong evidence for a bidirectional link between opioid and cholinergic systems and the obtained results potentially have impact on the future research focused on delineating the relative contributions of immune, neural and endocrine pathways in the regulating of gastrointestinal milieu. Firstly, the extension of knowledge on physiological interactions between hormones, enzymes and neurotrasmitters as well as receptors may help to predict, prevent and cure various GI diseases. Secondly, overdosing of opiates in animals and humans (analgesic, antiinflammatory drugs) causes disorders of GI tract, slows down the growth and development, which means thatfutureworkshouldfocusalso on this aspect. And, thirdly and foremost, these results may have to help understand the impact of various feed additives on the modulation of the GI tract activity. Recent articles present positive (Herosimczyk et al., 2018; Dupak et al., 2020) or negative (Dziedzic et al., 2019; Kapp-Bitter et al., 2020) aspects of feed additives (inulin, plant antioxidants, menhaden oil, tannins) on the proteome, metabolism and antioxidant status of animals that clearly indicates that further work is needed to better understand the mechanisms by which different additives can differentially affect neuroendocrine GI functioning.

\section{Conclusions}

It may be suggested that acetylocholine affects the ghrelin and gastrin release mainly by muscarinic receptors. The interaction of opioids and acetylcholine in the regulation of synthesis, concentration and release of peptidergic hormones from the rat intestine was clearly shown.

\section{Acknowledgements}

The study was supported by University of Agriculture in Krakow (grant No. Sub. 020002D015).

\section{References}

Abrams P., Andersson K.E., Buccafusco J.J. et al., 2006. Muscarinic receptors: their distribution and function in body systems, and the implications for treating overactive bladder. $\mathrm{Br}$. J. Pharmacol. 148, 565-578, https://doi.org/10.1038/ sj.bjp. 0706780

Albuquerque E.X., Pereira E.F., Alkondon M., Rogers S.W., 2009. Mammalian nicotinic acetylcholine receptors: from structure to function. Physiol. Rev. 89, 73-120, https://doi.org/10.1152/ physrev.00015.2008
Altarifi A.A., Bethany D., Karan H., Muchhala K.H., Blough B.E., Akbarali H., Negus S.S., 2017. Effects of acute and repeated treatment with the biased mu opioid receptor agonist TRV130 (oliceridine) on measures of antinociception, gastrointestinal function and abuse liability in rodents. J. Psychopharmacol. 31, 730-739, https://doi.org/10.1177/0269881116689257

AVMA (American Veterinary Medical Association), 2020. AVMA Guidelines for the Euthanasia of Animals: 2020 Edition. Version 2020.0.1. Schaumburg, IL (USA)

Copps J., Murphy R.F., Lovas S., 2009. The production and role of gastrin-17 and gastrin-17-gly in gastrointestinal cancers. Protein Pept. Lett. 16, 1504-1518, https://doi. org/10.2174/092986609789839269

Dupak R., Jaszcza K., Kalafova A., Schneidgenova M., Ivanisova E., Tokarova K., Brindza J., Capcarova M., 2020. Characterization of compounds in Cornelian cherry (Cornus mas L.) and its effect on interior milieu in ZDF. Emir. J. Food Agric. 32, 368-375, https://doi.org/10.9755/ejfa.2020.v32.15.2106

Dyaczyński M., Drożdż M., Wylężek L., Scanes C.G., Rzepa A., Pierzchała-Koziec K., 2020. Opioid-like peptides and ghrelin mitigation of bariatric results depends on obesity level. Endokrynol. Pol. 71, 27-33, https://doi.org/10.5603/ EP.a2019.0044

Dyaczyński M., Scanes C.G., Koziec H., Pierzchała-Koziec K., 2018. Endocrine implications of obesity and bariatric surgery. Endokrynol. Pol. 69, 574-597, https://doi.org/10.5603/ EP.2018.0059

Dziedzic B., Zgórzyńska E., Bewicz-Binkowska D., Walczewska A., 2019. A diet rich in menhaden oil has the hypolipidemic effect but increases plasma glucose and insulin levels in rats. J. Anim. Feed Sci. 28, 62-68, https://doi.org/10.22358/ jafs/104432/2019

Foong J.P., Hirst C.S., Hao M.M., McKeown S.J., Boesmans W., Young H.M., Bornstein J.C., Vanden Berghe P., 2015. Changes in nicotinic neurotransmission during enteric nervous system development. J. Neurosci. 35, 7106-7115, https://doi. org/10.1523/JNEUROSCI.4175-14.2015

Galligan J.J., Sternini C., 2017. Insights into the role of opioid receptors in the GI tract: experimental evidence and therapeutic relevance. Handb. Exp. Pharmacol. 239, 363-378, https:// doi.org/10.1007/164_2016_116

Goldspink D.A., Reimann F., Gribble F.M., 2018. Models and tools for studying enteroendocrine cells. Endocrinology 159, 3874-3884, https://doi.org/10.1210/en.2018-00672

Gribble F.M., Reimann F., 2019. Function and mechanisms of enteroendocrine cells and gut hormones in metabolism. Nat. Rev. Endocrinol. 15, 226-237, https://doi.org/10.1038/ s41574-019-0168-8

Herosimczyk A., Lepczyński A., Ożgo M., Barszcz M., Marynowska M., Tuśnio A., Taciak M., Markulen A., Skomiał J., 2018. Proteome changes in ileal mucosa of young pigs resulting from different levels of native chicory inulin in the diet. J. Anim. Feed Sci. 27, 229-237, https://doi.org/10.22358/jafs/93737/2018

Holzer P., 2009. Opioid receptors in the gastrointestinal tract. Regul. Pept. 155, 11-17, https://doi.org/10.1016/j.regpep.2009.03.012

Impicciatore M., Walsh J.H., Grossman M.I., 1977. Low doses of atropine enhance serum gastrin response to food in dogs. Gastroenterology 72, 995-996, https://doi.org/10.1016/ S0016-5085(77)80243-6

Kapp-Bitter A.N., Dickhoefer U., Suglo E., Baumgartner L., Kreuzer M., Leiber F., 2020. Graded supplementation of chestnut tannins to dairy cows fed protein-rich spring pasture: effects on indicators of protein utilization. J. Anim. Feed Sci. 29, 97-104, https://doi.org/10.22358/jafs/121053/2020 
Kokrashvili Z., Rodriguez D., Yevshayeva V., Zhou H., Margolskee R.F., Mosinger B., 2009. Release of endogenous opioids from duodenal enteroendocrine cells requires Trpm5. Gastroenterology 137, 598-606, https://doi.org/10.1053/j. gastro.2009.02.070

Kowalski C., Giruad P., 1993. Dopamine decreases striatal enkephalin turnover and proenkephalin messenger RNA abundance via $D_{2}$ receptor activation in primary striatal cell cultures. Neuroscience 53, 665-672, https://doi.org/10.1016/03064522(93)90614-L

Lang M.E., Davison J.S., Bates S.L., Meddings J.B., 1996. Opioid receptors on guinea-pig intestinal crypt epithelial cells. J. Physiol. 497, 161-171, https://doi.org/10.1113/jphysiol.1996. sp021757

Lewin M.J., 1992. The somatostatin receptor in the GI tract. Annu. Rev. Physiol. 54, 455-468, https://doi.org/10.1146/annurev. ph. 54.030192 .002323

Lightman S.L., Young W.S.III., 1987. Changes in hypothalamic preproenkephalin A mRNA following stress and opiate withdrawal. Nature 328, 643-645, https://doi. org/10.1038/328643a0

Lowry O.H., Rosebrough N.J., Farr A.L., Randall R.J., 1951. Protein measurement with the Folin phenol reagent. J. Biol. Chem. $193,265-275$

Makowska K., 2019. Changes in the expression of somatostatin (SOM) in nerve fibers of gastrointestinal mucosa in dogs with inflammatory bowel disease (IBD). Med. Case Rep. 5, 1:90, 1-6, https://doi.org/10.21767/2471-8041.100131

Montgomery L.E., Tansey E.A., Johnson C.D., Roe S.M., Quinn J.G., 2016. Autonomic modification of intestinal smooth muscle contractility. Adv. Physiol. Educ. 40, 104-109, https://doi. org/10.1152/advan.00038.2015

Owczarek D., Cibor D., Mach T., Ciesla A., Pierzchala-Koziec K., Salapa K., 2011. Met-enkephalins in patients with inflammatory bowel diseases. Adv. Med. Sci. 56, 158-164, https://doi.org/10.2478/v10039-011-0051-x
Parker C.E., Nguyen T.M., Segal D., MacDonald J.K., Chande N., 2018. Low dose naltrexone for induction of remission in Crohn's disease. Cochrane Database Syst. Rev. 2018, 4, CD010410, https://doi.org/10.1002/14651858.CD010410

Pierzchała-Koziec K., 2012. Ghrelin is multifaceted hormone. Acta Biol. Cracov. Ser. Zool. 54, 5-9

Pierzchala K., Van Loon G.R., 1990. Plasma native and peptidasederivable Met-enkephalin responses to restraint stress in rats. Adaptation to repeated restraint. J. Clin. Invest. 85, 861-873, https://doi.org/10.1172/JCl114513

Scerif M., Goldstone A.P., Korbonits M., 2011. Ghrelin in obesity and endocrine diseases. Mol. Cell Endocrinol. 340, 15-25, https:// doi.org/10.1016/j.mce.2011.02.011

Skulsky E.M., Nadir B.S., Osman I., Baghdoyan H.A., Lydic R., 2007. Microdialysis delivery of morphine to the hypoglossal nucleus of Wistar rat increases hypoglossal acetylcholine release. Sleep 30, 566-573, https://doi.org/10.1093/sleep/30.5.566

Sobczak M., Sałaga M., Storr M.A., Fichna J., 2014. Physiology, signaling, and pharmacology of opioid receptors and their ligands in the gastrointestinal tract: current concepts and future perspectives. J. Gastroenterol. 49, 24-45, https://doi. org/10.1007/s00535-013-0753-x

Takeuchi T., Tanaka K., Nakajima H., Matusi M., Azuma Y-T., 2006. M2 and M3 muscarinic receptors are involved in enteric nervemediated contraction of the mouse ileum: findings obtained with muscarinic-receptor knockout mouse. Am. J. Physiol. Gastrointest. Liver. Physiol. 292, G154-G164, https://doi. org/10.1152/ajpgi.00173.2006

Thompson G.L., Canals M., Poole D.P., 2014. Biological redundancy of endogenous GPCR ligands in the gut and the potential for endogenous functional selectivity. Front. Pharmacol. 5, 262, https://doi.org/10.3389/fphar.2014.00262 